\title{
MODULATION OF NONSPECIFIC DEFENCE MECHANISMS AND PROTECTION AGAINST DISEASES IN FISH
}

\author{
A. K. SIWICKI ${ }^{1.5}$, M. MORAND 2 , P. KLEIN ${ }^{3}$, M. STUDNICKA ${ }^{+}$, E. TERECH-MAJEWSKA ${ }^{5}$ \\ ${ }^{1}$ Department of Fish Pathology and Immunology IFI, Piaseczno, Poland \\ ${ }^{2}$ Laboratoire Departemental d'Analyses Conseil General du Jura, Lons le Saunier. France \\ ${ }^{3}$ Nika Health Products, Princeton, New Jersey, USA \\ ${ }^{4}$ Department of Physiology and Toxicology Catholic University in Lublin, Poiand \\ ${ }^{5}$ Department of Epizootiology with Clinic of Infection Diseases, \\ Faculty Veterinary Medicine University in Olsztyn, Poland
}

Received Julv 22, 1998

Accepted September 21, 1998

\begin{abstract}
Siwicki, A. K., M. Morand, P. Klein, M. Studnicka. E. Terech-Majewska: Modulation of Non-specific Defence Mechanisms and Protection against Diseases in Fish. Acta vet. Brno, 1998, 67: 323-328.

The use of immunomodulators in fish culture offers a wide range of attractive methods for inducing or modulating protection against diseases. Several promising synthetic drugs and biological response modifiers stimulate or modulate the nonspecific defence mechanisms and specific cellular and humoral immune responses in fish. This article reviews the literature on the influence of biostimulants on the cellular and humoral defence mechanisms in fish, and present the possibility to application of immunostimulants for control of infectious diseases in aquaculture.
\end{abstract}

\section{Fish, immunostimulants, defence mechanism.s}

Protection of fish against bacterial diseases by specific vaccines has been an important method for many years in aquaculture. However, defence mechanisms in the lower vertebrates are somewhat different from those in mammals, and some immunization techniques when actually applied to hatchery conditions are not as effective as they should be. Therefore, research is concentrating on how to improve the potency and efficacy of the antigens and how to optimally activate the nonspecific defence mechanisms and specific cellular and humoral immune responses. When a fish initially encounters a pathogen, the nonspecific defence mechanisms are more important than the specific immune response, as the latter requires a long time for antibody build-up and specific cellular activation. In general, fish have short life spans and most live in cool water environments which slows development of the specific immune response.

\section{Nonspecific defence barriers and mechanisms}

The nonspecific defence barriers already in place include physical epithelial shield of the scales, skin and the mucus. If an infectious agent is entrapped by the mucopolysaccharide complexes of the mucus, it may be scuffed from the fish or held to be digested by the mucus lytic enzymes. In most cases, the pathogenic microorganisms are destroyed by digestive and lytic enzymes. Inflammation may result at a tissue-damaged site, resulting in the migration of leukocytes to wound areas and the elevation of serum component concentrations, including C-reactive protein, transferrin, lysozyme, ceruloplasmine and complement components.

Address for correspondence:

A. K. Siwicki

Department of Fish Pathology

and Immunology IFI

05-500 Piaseczno. Poland

Phone: +48227562490

Fax: +48 227562490

E-mail: irs@warman.com.pl 
Phagocytes and phagocytosis are the main tools of the nonspecific immune response to pathogenic factors such as viruses, bacteria and parasites. The effector functions of phagocytes are considerable, but most important is their ability to kill pathogens. Both PMN and MN phagocytic cells arrive at a site of inflammatory reaction by chemotaxis. They may then attack microorganisms via their nonspecific cell surface receptors, or if the microorganism is opsonized with the fragment of the complement component $(\mathrm{C} 3 \mathrm{~b})$ through activation of the complement system, attachment will be through the cell surface receptors for $\mathrm{C} 3 \mathrm{~b}$. If the membrane does not become activated by the attached infectious agent, this is engulfed into a phagosome by pseudopods which extend around it. Once inside, lysosomes fuse with the phagosome forming a phagolysosome and the infectious agent is killed by a battery of microbicidal mechanisms.

Viral agents may induce the production of interferons by viral-infected cells, stimulate other cells to activate intracellular endonucleases that will destroy viral DNA and RNA and will shut down physiological pathways that viruses use for replication. This phenomenon is mediated by a population of nonspecific cytotoxic (NC) cells. Similar to natural killer (NK) cells, the NC cells are non-T, non-B cells which are not phagocytic. Compared to NK cells, NC cells produce very high levels of in vitro cytotoxicity against a wide variety of mouse and human target cells.

\section{Specific immune response}

Antibody is the primary result of the specific immune response, and unique in the fish physiology because these immunoglobulin molecules are specifically directed against individual antigens. The common Ig in fish is a tetrameric form of antibody and is usually designated as IgM. By contrast, the dimeric form is common (IgG) and efficient in mammals with a pentameric form ( $\operatorname{IgM})$ being a molecule produced early in infection or immunization. The antibody is a recognition molecule and as such has several function :

- it can complex with antigens and initiate other serum proteins to begin a complement cascade in lysing invasive pathogen,

- it can be stationary or attached to cells or act as a communicator to direct circulating cytotoxic cells to recognise and attack pathogenic agents.

The initiation of the specific immune response is controlled by $\mathrm{MN}$ phagocytic cells (antigen presenting cells - APC) involved in particle or antigen uptake. The information concerning what to make antibody against is transferred to the $\mathrm{B}$ cells. Complex receptors on the cells, such as the major histocompatibility complexes (MHCs), that guide the selection of the antibody, assisted by messenger chemical molecules, cytokines and interleukins, that are involved in the expression and control antibody secretion. Many of these messenger molecules are produced by subpopulation of T-lymphocytes, cytotoxic cells and phagocytes. Indeed, many of these cells, armed by information on what to attack physically participate in destruction of the pathogens. The specific immune response, in contrast to nonspecific defence mechanisms, can hold memory, and when the animal meet the pathogen for a second time, antibody is more rapidly produced and in a greater quantity.

\section{Modulation of cellular and humoral immunity}

The immune status of fish held in hatcheries, farms and aquaculture netpens is negatively effected by many factors: including polyetiological stress, environment pollution and treatments with chemotherapeutics (Anders on 1990; Dunier et al. 1991; Dunier and Siwicki 1993; Siwicki et al. 1997; Studnicka et al. 1997; Van Muisvinkel et al. 1985; Wishkowsky et al. 1987). The effects of these factors may impair the protective mechanisms of the fish and together with the accumulation of various flora in aquatic environment, conditions become favourable to the occurrence of infectious diseases, frequently with a mixed etiology. Therefore, it is of great importance to study the early detection of immune deficiencies and the stimulation or modulation of nonspecific cellular 
and humoral immunity. The use of immunomodulators and adjuvants in fish culture offers a wide range of attractive methods for inducing and modulating protection against diseases. But the exact mechanism of action by immunostimulant and/or immunomodulator on the biophysical pathways is often unknown. In general, immunostimulants and/or immunomodulators comprise a group of synthetic and biological compounds that enhance the cell-mediated and humoral-mediated immunity in animals. Some of them only stimulate the defence mechanism, others are able to restore or modulate immunity after suppression induced by xenobiotics. The stimulation of the defence mechanism may be particularly important for fish that are raised in or released to environments where the species or serotypes of pathogens are unknown and immunization by specific vaccines may be futile.

Several promising adjuvants, drugs and biological modifiers have been tested in vitro and in vivo in fish. A summary of biostimulants and/or biomodulators used for activation or restoration the nonspecific defence mechanisms in fish and specific immune responses are presented in Table 1 .

Table 1.

The influence of biostimulants and /or biomodulators on the cellular and humoral defence mechanisms in fish - summary from published scientific papers.

\begin{tabular}{|c|c|c|}
\hline Biomodulator & Results & References \\
\hline Bacille Calmette Guerin (BCG) & increased & Grayson et al. 1987 \\
\hline Boviglobin & increased & Siwicki et al. 1996 \\
\hline Candida utilis (yeast) & increased & Siwicki et al. 1994 \\
\hline Ceromangan & increased & Siwicki et al. 1996 \\
\hline CFA (modified) & increased & Olivier et al. 1985 \\
\hline Chitosan & $\begin{array}{l}\text { increased } \\
\text { modulated }\end{array}$ & $\begin{array}{l}\text { Siwicki et al. } 1994 \\
\text { Anderson, Siwicki } 1994\end{array}$ \\
\hline Evetsel & increased & Siwicki et al. 1994 \\
\hline FinnStim & increased & Siwicki et al. 1994 \\
\hline FK-565 & increased & Kitao et al. 1986 \\
\hline Glucan 1,3 & increased & Yano et al. 1989 \\
\hline M-Glucan & increased & Robertsen et al. 1990 \\
\hline B-glucan & increased & $\begin{array}{l}\text { Nikl et al. } 1991 \\
\text { Siwicki et al. } 1994\end{array}$ \\
\hline HMB & increased & Siwicki et al. 1998 \\
\hline ISK & increased & Jeney and Anderson 1993 \\
\hline Lysozyme dimer (KLP-602) & $\begin{array}{l}\text { increased } \\
\text { modulated } \\
\text { modulated } \\
\text { modulated }\end{array}$ & $\begin{array}{l}\text { Morand et al. } 1998 \\
\text { Klein et al. } 1997 \\
\text { Studnicka et al. } 1998 \\
\text { Siwicki et al. } 1998\end{array}$ \\
\hline Saccharomyces cerevisiae & increased & Siwicki et al. 1994 \\
\hline $\begin{array}{l}\text { Watasenia scintillans } \\
\text { (heat extract) }\end{array}$ & increased & Siwicki et al. 1996 \\
\hline
\end{tabular}


Complete Freund's adjuvant (CFA) was one of the first immunostimulants used in animals and humans to elevate the specific immune response, and it has also successfully been used in conjunction with the injection of the bacterins (Olivier et al. 1985). Other immunostimulants and biological response modifiers that have been used in fish research include synthetic levamisole (Siwicki and Anderson 1990), bacterial lipopolysaccharides and glucans ( $\mathrm{Y}$ a no et al. 1989). Vaccines have been adsorbed to inert particles, such as bentonite and latex beads to carry the immunogens in attempts to maximise in vivo uptake for bath immunization and to facilitate in vitro phagocytosis. Each substance presents special problems in timing and methods of administration by injection, immersion, orally or flush treatments, and dosage adjustments for size and fish species. An additional consideration is that the nonspecific defence mechanisms and specific cellular and humoral responses are highly variable among individuals and statistical validation requires appropriate sample numbers and carefully controlled experiments. The preliminary studies, assaying the influence of the biostimulants can be done in vitro (Siwicki et al. 1990).

The influence of immunomodulators on the fish cellular defence mechanisms can be followed by taking samples of nonlethal blood and haematopoietic organs and observing changes in leukocyte numbers, activity and functions. Macrophages/monocytes, neutrophils and other phagocytic cells increase the enzyme mobilisation, oxidative radical production and phagocytic activities. The subpopulations of $\mathrm{T}$ lymphocytes increase the proliferative responses and cytotoxic activity, as well as increase the proliferative response of B lymphocytes and level of antibody secreting cells. The effect of stimulants on fish humoral defence mechanisms can be followed in blood samples analysed for changes serum or plasma total Ig and specific antibody levels, lysozyme and ceruloplasmin activity and cytokines levels (Anderson 1992; Anderson et al. 1992; Siwicki and Anderson 1993; Siwicki et al. 1993).

Immunostimulants may be used in patterns similar to those of chemotherapeutics or chemicals and in combination with vaccines. The fish could be prepared for a predicted event, such as seasonal exposure to pathogens or handling stress, by a treatment prior to the event. Many environmental and physiological variables will influence experiments and protocol for the use of immunostimulants in fish, including timing, dosage requirements, environmental temperature, stability of each component, the characteristics of the vaccine and species of fish. The first consideration is whether the substance is to be used alone as a single treatment or whether it will be used in conjunction with an immunization program.

Several fish food manufactures now offer diets supplemented with biostimulants for use in aquaculture. Currently recommended schedules for feeding some immunostimulants call for administration every day for 1 to 2 weeks (Onarheim 1992). Many questions remain concerning the regimens and use of immunostimulants, particularly as to routes of administration, appropriate dosages, time and length of application, and influence on the environment.

\section{Modulace nespecifických obranných mechanismů a ochrana před nemocemi u ryb}

Užití imunomodulátorů v rybářství nabízí široké spektrum atraktivních metod pro indukci nebo modulaci ochrany před nemocemi. Některá nadějná syntetická léčiva a biologické odpovědi modifikují stimulačně nebo modulačně nespecifické obranné mechanismy a specifické buněčné nebo humorální imunologické odpovědi ryb. Příspěvek obsahuje přehled literárních údajů o vlivu biostimulantů na buněčné a humorální obrané mechanismy ryb a předkládá možnost aplikace imunostimulačních látek pro kontrolu infekčních nemocí v akvakultuře. 


\section{References}

ANDERSON. D. P. 1990: Immunological indicators: effects of environmental stress on immune protection and disease outbreaks. Am. Fish. Soc. Symp. 8: 38-50

ANDERSON, D. P. 1992: Immunostimulants, adjuvants, and vaccine carriers: applications to aquaculture. Annu. Rev. Fish Dis. 2: 281-307

ANDERSON, D. P., SIWICKI, A. K. 1994: Duration of protection against Aeromonas salmonicida in brook trout immunostimulated with glucan of chitosan by injection or immersion. Progress. Fish Cultur. 56: 258-261

ANDERSON, D. P., MORITOMO, T., DE GROOTH, R. 1992: Neutrophil. glass-adherent, nitroblue tetrazolium assay gives early indication of immunization effectiveness in rainbow trout. Vet. Immunol. Immunopathol. 30: 419-429

CYPRIANO, R. C. PYLE. S. W. 1985: Adjuvant-dependent immunity and the agglutinin response of fishes against Aeromonas salmonicida cause of furunculosis. Can. J. Fish. Aquat. Sci. 42: 1290-1295

DUNIER, M., SIWICKI. A. K., DEMAEL, A. 1991: In vivo effect of the organophosphorus insecticide trichlorphon on the immune response of carp (Cyprinus carpio). Ecotox. Envir. Safety 22: 79-87

DUNIER, M., SIWICKI, A. K. 1993: Effects of pesticides and other organic pollutants in the aquatic environment on immunity of fish: a review. Fish Shellfish Immunol. 3: 423-438

GRAYSON, T. H., WILLIAMS, R. J., WRATHMELL, A. B., MUNN, C. B.. HARRIS, J. E. 1987: Effects of the immunopotentiating agents on the immune responses of rainbow trout, Salmo gairdneri, to ERM vaccine. J. Fish Biol. 31: 195-202

JENEY, G., ANDERSON, D. P. 1993: Enhanced immune response and protection in rainbow trout to Aeromonas salmonicida bacterin following prior immersion in immunostimulants. Fish Shellfish Immunol. 3: $51-58$

KLEIN, P., SIWICKI, A. K., MORAND, M. 1997: Immunomodulating activity of dimerized lysozyme (KLP-602) after suppression induced by infectious pancreatic necrosis virus (IPNV). Wplyw Ksenobiotykow na Uklad Odpornosciowy. IRS Olsztyn 1: 195-205

KITAO, T., YOSHIDA, Y. 1986: Effect of an immunopotentiator on Aeromonas salmonicida infection in rainbow trout (Salmo gairdneri). Vet. Immunol. Immunopathol. 12: 287-296

MORAND, M., SIWICKI, A. K., POZET, F., KLEIN, P., VINAIZE, J. K., KECK, N. 1998: Effects of dimerized lysozyme (KLP-602) on the cellular and humoral defence mechanisms in sheatfish (Silurus glanis): in vitro and in vivo study. Vet. Res. - in press

NIKL, L., ALBRIGHT, L. J., EVELYN, T. P. T. 1991: Influence of seven immunostimulants on the immune response of coho salmon to Aeromonas salmonicida. Dis. Aquat. Anim. 12: 7-12

OLIVIER, G., EVELYN, T. P. T., LALLIER, R. 1985: Immunity to Aeromonas salmonicida in coho salmon (Oncorhynchus kisutch) induced by modified Freund's complete adjuvant. Lab. Anim. 20: 25-30

ONARHEIM, A. M. 1992: Now a yeast extract to fortify fish. Fish Farmer 15: 45

ROBERTSEN, B., RORSTAD, G., ENGSTAD, R., RAA, J. 1990: Enhancement of non-specific disease resistance in Atlantic salmon. Salmo salar by a glucan from Saccharomyces cerevisiae cell walls. J. Fish Dis. 13: 391-400

SIWICKI. A. K., ANDERSON. D. P. 1990: Study of the effect of levamisole on the nonspecific immune response in carp (Cyprinus carpio). Annales Universitas Marie Curie-Sklodowska Polonia 8: 59-64

SIWICKI, A. K., ANDERSON, D. P., DIXON, O. W. 1990: In vitro immunostimulation of rainbow trout (Oncorhynchus mykiss) spleen cells with levamisole. Dev. Comp. Immunol. 14: 231-237

SIWICKI, A. K., ANDERSON, D. P. 1993: Immunostimulation in Fish: Measuring the Effects of Stimulants by Serological and Immunological Methods. U.S. Fish and Wildlife Service. IFI, Poland 1, 24 p.

SIWICKI. A. K.. ANDERSON, D. P., WALUGA, J. 1993: Fish Diseases Diagnosis and Preventions Methods. IRS Olsztyn, Poland, 181 p.

SIWICKI. A. K., ANDERSON. D. P., RUMSEY, G. L. 1994: Dietary intake of immunostimulants by rainbow trout affects nonspecific immunity and protection against furunculosis. Vet. Immunol. Immunopathol. 41: $125-139$

SIWICKI. A. K.. MIYAZAKI. T., KOMATSU, I.. MATSUSATO. T. 1996: In vitro influence of heat extract from firefly squid Watasenia scintillans on the phagocyte and lymphocyte activities in rainbow trout Oncorhynchus mykiss. Fish Pathol. 31: 1-7

SIWICKI. A. K., STUDNICKA. M., KLODZINKA. H. ANDERSON, D. P. 1996: Influence of boviglobin and ceromangan on the cellular and humoral immunity of carp spawners. The R..le of Aquaculture in World Fisheries 6: $180-186$

SIWICKI, A. K.. STUDNICKA, M., MORAND, M., RYMUSZKA, A. 1997: Modulowanie komorkowej i humoralnej odpowiedzi immunologicznej po supresji indukowanej chemoterapeutykami - badania eksperymentalne. Wplyw Ksenobiotykow na Uklad Odpornosciowy. IRS Olsztyn 1: 175-186

SIWICKI. A. K., KLEIN, P., MORAND, M., KICZKA. W.. STUDNICKA. M. 1998: Immunostimulatory effects of dimerized lysozyme (KLP-602) on the nonspecific defence mechanisms and protection against furunculosis in salmonids. Vet. Immunol. Immunopathol. - in press

SIWICKI. A. K., MORAND, M., GORYCZKO, K., OSTASZEWSKI. P.. FULLER, J., NISSEN, S. 1998: Immunomodulating effect of 3-hydroxy-3-methylbutyrate (HMB) on the nonspecific cellular and humoral defence mechanisms in raibnow trout (Oncorhynchus mykiss). ADSA-AS.AS Joint Meeting USA - in press

STUDNICKA. M., DUNIER, M., SIWICKI A. K., MORAND M. 1997: Zastosowanie biostymulatorow 
w korygowaniu reaktywnosci immunologicznej uposledzonej pestycydami fosforoorganicznymi. Wplyw Ksenobiotykow na Uklad Odpornosciowy. IRS Olsztyn 1: 187-194

STUDNICKA, M., SIWICKI, A. K., MORAND, M., RYMUSZKA, A., BOWNIK, A., TERECH-MAJEWSKA, E. 1998: Modulation of nonspecific defence mechanisms and specific immune responses after suppression induced by xenobiotics. J. App. Ichthyol. - in press

VAN MUISWINKEL. W. B., ANDERSON, D. P., LAMERS, C. H., EDBERTS, E., VAN LOON, J. J., IJSSEL, J. P. 1985: Fish immunology and fish health. Fish Immunology. Academic Press, London : 1-8

WISHKOWSKY, A., ROBERTSON, B., HETRICK, F. M. 1987: In vitro suppression of the fagocytic response of fish macrophages by tetracyclines. J. Fish Biol. 31: 61-65

YANO, T.. MANGINDAAN, R. E. P., MATSUYAMA, H. 1989: Enhancement of the resistence of carp Cvprinus carpio to experimental Edwardsiella tarda infecction by some B-1, 3-glucans. Nippon Suisan Gakkai-shi 55: $1815-181$ 